\title{
PENGEMBANGAN SOAL HIGH ORDER THINKING (HOT) MELALUI PEMBELAJARAN BERBASIS MASALAH UNTUK MELATIH KETERAMPILAN BERPIKIR KRITIS PESERTA DIDIK KELAS VI SD
}

\author{
Jamila K. Baderan \\ Pascasarjana \\ Universitas Negeri Gorontalo
}

\begin{abstract}
ABSTRAK
Penelitian ini bertujuan untuk mengembangkan soal-soal berdimensi HOT dalam pembelajaran tematik Tema 3 Tokoh dan Penemuan. Subjek penelitian ini adalah siswa kelas VI semester I tahun pelajaran 2017/2018 di SD Negeri No. 80 Kota Tengah Kota Gorontalo. Penelitian dan pengembangan ini menggunakan model pengembangan Plomp tipe formative evaluation, yang merujuk pada prosedur Tessmer. Penelitian ini terdiri dari dua tahap yaitu preliminary dan tahap formative evaluation yang meliputi self evaluation, expert reviews dan oneto-one (low resistance to revision) dan small group serta field test(high resistance in revision).Prototipe soal-soal berdimensi HOT yang dikembangkan dikategorikan valid. Valid tergambar dari hasil penilaian validator, dimana validator menyatakan baik berdasarkan konten, konstruk, dan bahasa. Berdasarkan proses pengembangan yang dilakukan diperoleh data bahwa prototipe soal-soal berdimensi HOT memiliki potensial efek terhadap hasil belajar. Hal ini terlihat dari hasil pekerjaan peserta didik pada saat proses pembelajaran dengan kategori baik.
\end{abstract}

Kata kunci :Soal HOT, Berpikir Kritis, Pembelajaran Berbasis Masalah

\section{A.PENDAHULUAN}

Salah satu tantangan pendidikan di Indonesia dewasa ini adalah bagaimana membangun keterampilan abad 21 sebagai indikator ciri masyarakat era global, yaitu masyarakat berpengetahuan (knowledge-based society). Adapun keterampilan yang harus dimiliki tersebut meliputi: (1) kemampuan berpikir kritis; (2) kemampuan berkomunikasi; (3) kemampuan mencipta dan membaharui; 
literasi teknologi informasi dan komunikasi; (5) kemampuan belajar kontekstual; dan (6) kemampuan informasi dan literasi media.

$\begin{array}{rrr}\text { Salah } & \text { satu upaya yang } \\ \text { dilakukan } & \text { pemerintah } & \text { untuk }\end{array}$
mengembangkan keterampilan tersebut dilakukan melalui pengimplementasian kurikulum 2013 dengan pendekatan saintifik. Penggunaan pendekatan ini diarahkan pada kegiatan mengamati, menebak, membuat, mencoba, dan menjawab pertanyaan sehingga kemampuan berpikir siswa diharapkan dapat berkembang dengan baik. Berpikir yang diarahkan pada pembelajaran tematik di sekolah dasar adalah kemampuan berpikir kritis.Salah satu cara yang dapat digunakan untuk memperkuat pendekatan scientific adalah melalui penggunaan model pembelajaran berbasis masalah (problem based learning).Salah satu model pembelajaran yang memungkinkan dikembangkannya keterampilan berpikir (penalaran, komunikasi dan koneksi) dalam memecahkan masalah adalah Pembelajaran
Berbasis Masalah (PBM) (Rusman dalam Saleh, Marhamah: 2013).

Problem Based Learning atau Pembelajaran Berbasis Masalah menempatkan peserta didik sebagai subjek yang memiliki kemampuan untuk secara aktif mencari, mengolah, mengkonstruksi, dan menggunakan

pengetahuan.

Pemilihan atau penentuan masalah nyata ini dapat dilakukan oleh guru maupun peserta didik yang disesuaikan kompetensi dasar tertentu. Masalah itu bersifat terbuka (open-ended problem), yaitu masalah yang memiliki banyak jawaban ataustrategi penyelesaian yang mendorong keingintahuan peserta didik untuk mengidentifikasi strategi-strategi dan solusi-solusi tersebut. Masalah yang digunakan dalam PBM berupa soal-soal dengan karakter high order thinking (HOT).

Pengembangan kemampuan berpikir kritis melalui soal-soal HOT pada jenjang sekolah dasar belum optimal. Kondisi ini nampak dari prestasi peserta didik Indonesia berdasarkan hasil studi Programfor International Student Assessment 
PEDAGOGIKA

Jurnal Ilmu Pendidikan

Volume 9 (Nomor 2) 2018

(PISA) tahun 2015 dimana Indonesia berada pada peringkat 69 dari 76 negara. Sedangkan dari hasil studi Trends in International Mathematics and Science Study (TIMSS), menunjukkan peserta didik Indonesia berada pada peringkat 36 dari 49 negara dalam hal melakukan prosedur ilmiah. Dari kedua hasil penelitian tersebut menunjukkan bahwa prestasi peserta didik Indonesia masih di bawah rata-rata. Kemampuan anak Indonesia secara ilmiah tetap dianggap masih rendah.

Hal ini didukung pula olehdata dan fakta tentang hasil belajar peserta didik khususnya di Kota Gorontalo selama tiga tahun terakhir, seperti tampak pada tabel berikut.

Tabel 1.1 Daftar Nilai USBN Kota Gorontalo

\begin{tabular}{|l|l|l|l|l|}
5 & IPS & 78.9 & 82.9 & 88.6 \\
\hline 6 & SBDP & $*$ & 82.6 & 84.6 \\
\hline
\end{tabular}

Sumber: Dinas Pendidikan Kota

Gorontalo

Ket. * Nilai praktek berada di sekolah

Kenyataan di lapangan menunjukkan bahwa sebagian besar peserta didik hanya menghafal konsep dan kurang mampu menggunakan konsep yang dimiliki untuk menyelesaikan masalah dalam kehidupan nyata yang berhubungan dengan konsep tersebut. Kemampuan peserta didik dalam menentukan dan merumuskan masalah juga masih kurang, dalam proses pembelajaran penyampaian muatan materi pelajaran belum optimal dimana metode ceramah konvensional masih

\begin{tabular}{|c|c|c|c|c|}
\hline \multirow[b]{2}{*}{ NO } & \multirow{2}{*}{$\begin{array}{l}\text { MATA } \\
\text { PELAJARAN }\end{array}$} & \multicolumn{2}{|c|}{ TAHUN AJARAN } & pembelajaran terkesan bersifat \\
\hline & & $\begin{array}{l}2014- \\
2015\end{array}$ & $\begin{array}{l}2015- \\
2016\end{array}$ & $\begin{array}{l}\mathbf{2 0 1 6} \text { her centered. Akibatnya peserta } \\
\mathbf{2} \text { dintik menjadi pasif. }\end{array}$ \\
\hline 1 & $\overline{P \text { PKN }}$ & 80.93 & 82.6 & Hal lain yang \\
\hline 2 & $\begin{array}{l}\text { BAHASA } \\
\text { INDONESIA }\end{array}$ & 76.61 & 72.93 & $\begin{array}{c}\text { masalah } \\
65.79 \\
\text { pengetahuan }\end{array}$ \\
\hline 3 & MATEMATIKA & 65.23 & 69.99 & menerapkan \\
\hline 4 & IPA & 70.63 & 74.64 & 7nembelajaran berbasis masalah atau \\
\hline
\end{tabular}


PEDAGOGIKA

Jurnal Ilmu Pendidikan

Volume 9 (Nomor 2) 2018

pembelajaran matematikadi sekolah dasar. Disamping itu, pemahaman guru tentang soal HOT serta kemampuan guru dalam membuat soal HOT masih kurang. Instrumen soal HOT yang khusus didesain untuk melatih keterampilan berpikir kritis bagi peserta didik yang mendukung pembelajaran berbasis masalah belum banyak dikembangkan. Instrumen soal yang digunakan oleh guru umumnya menggunakan butir soal yang terdapat di dalam buku teks, lembar kegiatan peserta didik, atau kumpulan soal yang sudah pernah diberikan kepada peserta didik. Keadaan tersebut membuat peserta didik cenderung lebih banyak menggunakan ingatan dalam menyelesaikan butir soal. Hedges (1986) dalam Hartini\& Sukardjo (2015:87) menyatakan bahwa penilaian dengan menggunakan butir soal yang sudah diketahui peserta didik akan cenderung menilai aspek kognitif pada dimensi mengingat. Guru juga belum efektif melatih kemampuan pemecahan masalah, sehingga siswa kurang bahkan tidak memiliki keterampilan berpikir kritis.

Proses pembelajaran di sekolah saat ini belum dapat mengembangkan keterampilan berpikir kritis, karena hanya berorientasi pada usaha mengembangkan dan menguji daya ingat peserta didik. Untuk mengatasi berbagai permasalahan tersebut, perlu adanya suatu pengembangan intrumen soal berdimensi $H O T$ yang dapat digunakan selama proses pembelajaran melalui problem-based learning (pembelajaran berbasis masalah) maupun pada saat penilaian hasil belajar untuk melatih keterampilan berpikir kritis peserta didik.

Penelitian ini bertujuan untuk menghasilkan soal-soal berdimensi HOT melalui pembelajaran berbasis masalahuntuk melatih keterampilan berpikir kritis peserta didik kelas VI SD.

\section{B.KAJIAN TEORI}

1. Ketrampilan Berpikir Kritis 
Keterampilan adalah istilah yang mengacu pada kemampuan atau keahlian khusus yang diperoleh melalui pengalaman atau latihan untuk melakukan tugas dengan baik. Keterampilan abad 21 sebagai ciri masyarakat era global adalah (1) life and career skills, (2) learning and innovation skills, dan (3) Information media and technology skills (Wijaya, Sudjimat \& Nyoto, 2016: 268). Selanjutnya Trillingand Fadel (2009:47) memberikan penjelasan bahwaLearning and innovation skills (keterampilan belajar dan berinovasi) meliputi (a) berpikir kritis dan mengatasi masalah/Critical Thinking and Problem Solving, (b) komunikasi dan kolaborasi/Communication and Collaboration, (c) kreativitas dan inovasi/Creativity and Innovation.

\section{Berpikir adalah suatu} kegiatan mental yang dilakukan untuk membantu memecahkan masalah, membuat keputusan, atau sekedar memenuhi rasa ingin tahu. Berpikir artinya menggunakan kemampuan analitis, kreatif, dan perlu praktek. Setiawan Wahyu (2015: 93) menyatakan, "Berpikir kritis adalah analitis dan refleksif". Hal ini berarti bahwa berpikir kritis meliputi beberapa kegiatan dalam satu proses yaitu memeriksa, menghubungkan, mengevaluasi, menyimpulkan serta mampu menentukan perbedaan atau pertentangan dari suatu informasi atau sekelompok data.

Dari pernyataan Florea dan Hurjui dapat disimpulkan bahwa berpikir kritis merupakan suatu proses aktif, terkoordinasi, dan kompleks yang melibatkan proses berpikir yang berawal dari kegiatan mengumpulkan informasi dan berakhir dengan sebuah keputusan dengan alasan yang baik.

$$
\text { Yaumi (2012: }
$$

menyatakan, "Berpikir kritis merupakan kemampuan kognitif dalam pengambilan kesimpulan berdasarkan alasan logis dan bukti empiris". Dengan demikian maka berpikir kritis merupakan suatu proses dimana otak manusia bekerja mencerna berbagai informasi/permasalah yang ada, lalu menghubungkannya dengan berbagai 
PEDAGOGIKA

Jurnal Ilmu Pendidikan

Volume 9 (Nomor 2) 2018

konsep awal yang ada, melalui berbagai pertimbangan alasan riil sehingga menghasilkan kesimpulan yang baik.

Berdasarkan pendapat beberapa ahli tersebut, dapat disimpulkan bahwa keterampilan berpikir kritis adalah kemampuan proses mental seseorang meliputi kemampuan analitis, evaluative, dan penalaran yang digunakan secara sistematis melalui pengalaman atau latihan khusus sehingga dapat membuat suatu keputusan atau tindakan yang baik.

Selama ini keterampilan belajar abad 21 telah banyak dikembangkan, tetapi sangat sedikit yang mengarahkan peserta didik untuk berlatih berpikir kritis dan pemecahan masalah.Berpikir kritis dan pemecahan masalah dianggap menjadi dasar baru untuk belajar abad 21. Sebab dengan menggunakan pengetahuan yang sedang dipelajari dan menerapkan keterampilan seperti berpikir kritis, pemecahan masalah, dan kreativitas untuk motivasi pengetahuan dapat meningkatkan hasil pembelajaran. Dalam suatu proses pembelajaran, kemampuan berpikir kritis peserta didik dapat dikembangkan dengan memperkaya pengalaman yang bermakna melalui persoalan pemecahan masalah.

Keterampilan berpikir kritis membekali dan menjadikan peserta didik mampu membuat keputusan atau tindakan untuk menghadapi setiap permasalahan yang dijumpainya dalam kehidupan sehari-hari. Kemampuan berpikir peserta didik sangat dipengaruhi oleh proses pembelajaran. Oleh karena itu, dalam proses pembelajaran guru harus dapat memberikan stimulus agar peserta didik dapat mengembangkan kemampuan berpikir kritis. Menurut Widiantari, Suarjana, \& Kusmariyatni (2016: 2) berpikir yang diarahkan dalam proses pembelajaran di sekolah dasar adalah kemampuan berpikir tingkat tinggi atau kemampuan berpikir kritis.

Banyak ahli yang telah menyusun indikator berpikir kritis guna memudahkan pengimplementasiannya di berbagai keperluan misalnya di bidang pendidikan. Karakteristik berpikir 
kritis diantaranya: (1) Merupakan proses bukan hasil, yang meliputi pertanyaan berlanjut pada asumsi; (2) Aktivitas yang produktif dan positif; (3) Emosi yang terpikir dengan baik; serta (4) Ingin tahu, fleksibel, jujur dan skeptical (Lumsdaine \& Lumsdaine: 1995, dalam Hartini \& Sukardjo: 2015, p.88).

Tujuan berpikir kritis tidak untuk menemukan solusi, tetapi untuk mengkonstruk sebuah gambaran logika pada situasi atau keadaan berdasarkan pendapat dan kejadian yang masuk akal, meskipun model kebenaran yang diperoleh tidak dapat diuji. Facione bersama 46 ahli lainnya telah berkolaborasi dalam melakukan penelitian kualitatif untuk mencari kesepakatan mengenai karakteristik keterampilan berpikir kritis di bidang pembelajaran dan mengembangkan cara yang efektif untuk membelajarkan serta menilai keterampilan berpikir kritis.

Hasil dari penelitian Facione tersebut ditetapkan bahwa karakteristik berpikir kritis merupakan aspek berpikir kritis yang dibuat agar dapat digunakan secara umum untuk kepentingan proses pembelajaran, sehingga dapat digunakan pada semua mata pelajaran. Penggunaan aspek berpikir kritis tersebut dalam proses pembelajaran tertentu perlu disesuaikan dengan karakteristik proses pembelajaran.Belajar berpikir kritis tidak langsung seperti belajar tentang materi, tetapi belajar bagaimana cara berpikir kritis dalam penggunaanya untuk memecahkan masalah yang saling berkaitan satu sama lain. Keterampilan berpikir peserta didik dapat dilatihkan melalui kegiatan dimana peserta didik diberikan suatu masalah, dalam hal ini masalah berbentuk soal yang bervariasi (Prayugo, 2012 dalam Saputra: 2015).

Pada penelitian pengembangan soal HOT ini, aspek berpikir kritis yang digunakan sebagai indikator keterampilan berpikir kritis meliputi 9 aspek, yaitu: menghubungkan, menginterpretasi, membandingkan dan membedakan, mengelompokkan dan mengklasifikasi, mengurutkan, menganalisis, mengevaluasi, 
PEDAGOGIKA

Jurnal Ilmu Pendidikan

Volume 9 (Nomor 2) 2018

membuat simpulan, dan Prinsip utama PBM adalah menjelaskan. Adapun indikator untuk mengukur kemampuan berpikir kritis dapat diturunkan dari aktivitas kritis siswa sebagai berikut:

(1) Memaknai pertanyaan atau pernyataan; (2) Menghubungkan informasi, pengetahuan, dan inti pernyataan atau pertanyaan; (3) Bersikap dan berpikir terbuka terhadap ide-ide dari luar; (4) Bersikap dan berpikir secara sistematis, menghubungkan bagianbagian system menjadi satu kesatuan (Anto: 2010, dalam Rahmawati, Yani, \& Nurlina 2015: 266).

2.Pembelajaran Berbasis Masalah (Problem-based Learning)

\section{a. Pengertian Pembelajaran}

\section{Berbasis Masalah}

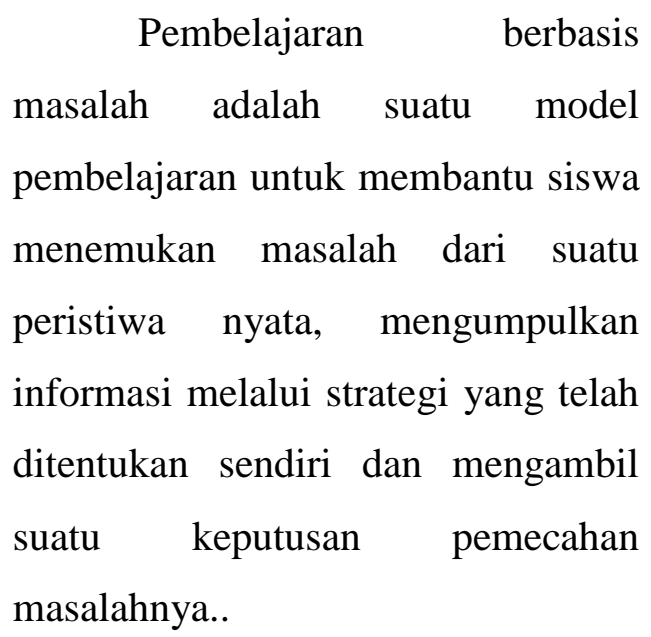

Pembelajaran berbasis instruction method in which students take on an active role in their own learning." Dengan demikian dalam pembelajaran berbasis masalah, peserta didik merupakan pusat pembelajaran atau student-centered, sementara guru berperan sebagai fasilitator yang memfasilitasi peserta didik untuk secara aktif menyelesaikan masalah dan membangun pengetahuannya secara 
PEDAGOGIKA

Jurnal Ilmu Pendidikan

Volume 9 (Nomor 2) 2018

berpasangan ataupun berkelompok

memperoleh pengetahuan dan (kolaborasi antar peserta didik).

Astika dkk (2013), konsep yang esensial dari materi pelajaran yang disajikan.

mengemukakan bahwa pembelajaran berbasis masalah merupakan model pembelajaran yang berorientasi pada kerangka teoretik konstruktivisme. Teori konstruktivis ini menyatakan bahwa siswa harus menemukan sendiri dan mentransformasikan informasi kompleks, mengecek informasi baru berdasarkan aturanaturan lama dan merevisinya apabila aturan itu tidak lagi sesuai. Agar peserta didik benar-benar memahami dan dapat menerapkan pengetahuan, mereka harus bekerja memecahkan masalah, menemukan segala sesuatu untuk dirinya dengan cara mencari ide-ide.

Dari uraian di atas dapat disimpulkan bahwa pembelajaran berbasis masalah adalah suatu model pembelajaran yang menyajikan masalah dunia nyata di awal pembelajaransebagai suatu konsep yang hendak dipelajari peserta didik secaraaktif agar peserta didik mampu mengembangkan keterampilan berpikir kritis dan keterampilan pemecahan masalah, serta untuk

\section{b. Karakteristik} Pembelajaran Berbasis Masalah

Menurut paham kosntruktivisme, manusia hanya dapat memahami melalui segala sesuatu yang dikonstruksinya sendiri. Pembelajaran berbasis masalah memiliki gagasan bahwa pembelajaran dapat dicapai jika kegiatan pendidikan dipusatkan pada tugas-tugas atau permasalahan yang otentik, relevan, dan dipresentasikan dalam suatu konteks. Cara tersebut bertujuan agar peserta didikmemilki pengalaman sebagaiamana anantinya mereka hadapi di kehidupan profesionalnya. Pengalaman tersebut sangat penting karena pembelajaran yang efektif dimulai dari pengalaman konkrit. Pertanyaan, pengalaman, formulasi, serta penyusunan konsep tentang pemasalahan yang mereka ciptakan sendiri merupakan dasar untuk pembelajaran. 
PEDAGOGIKA

Jurnal Ilmu Pendidikan

Volume 9 (Nomor 2) 2018

Berdasarkan teori yang pengetahuan secara kolaborative, dikembangkan Barrow, Min Liu (2005) menjelaskan karakteristik dari PBM, yaitu : (1)Learning is studentcentered. Proses pembelajaran dalam PBL lebih menitikberatkan kepada siswa sebagai orang belajar. Oleh karena itu, PBL didukung juga oleh teori konstruktivisme dimana siswa didorong untuk dapat mengembangkan pengetahuannya sendiri. (2)Authentic problems form the organizing focus for learning. Masalah yang disajikan kepada siswa adalah masalah yang otentik sehingga siswa mampu dengan mudah memahami masalah tersebut serta dapat menerapkannya dalam kehidupan profesionalnya nanti. (3)New information is acquired through self-directed learning. Dalam proses pemecahan masalah mungkin saja siswa belum mengetahui dan memahami semua pengetahuan prasyaratnya, sehingga siswa berusaha untuk mencari sendiri melalui sumbernya, baik dari buku atau informasi lainnya. (4)Learning occurs in small groups. Agar terjadi interaksi ilmiah dan tukar pemikiran dalam usaha membangun maka PBM dilaksakan dalam kelompok kecil. Kelompok yang dibuat menuntut pembagian tugas yang jelas dan penetapan tujuan yang jelas. (5)Teachers act as facilitators. Pada pelaksanaan PBM, guru hanya berperan sebagai fasilitator. Namun, walaupun begitu guru harus selalu memantau perkembangan aktivitas siswa dan mendorong siswa agar mencapai target yang hendak dicapai.

Berdasarkan pendapat Arends yang disimpulkan dalam Trianto (2014:68), pembelajaran berdasarkan masalah (problem-based learning) pada dasarnya memiliki karakteristik: (a) Mengorientasikan siswa kepada masalah autentik dan menghindari pembelajaran terisolasi; (b) Berpusat pada siswa dalam jangka waktu lama; (c) Menciptakan pembelajaran interdisiplin;

Penyelidikan masalah autentik yang terintegrasi dengan dunia nyata dan pengalaman praktis; Menghasilkan produk/karya dan memamerkannya; (f) Mengajarkan kepada siswa untuk mampu menerapkan apa yang mereka 
PEDAGOGIKA

Jurnal Ilmu Pendidikan

Volume 9 (Nomor 2) 2018

pelajari di sekolah dalam kehidupannya yang panjang; (g) Pembelajaran terjadi pada kelompok kecil (kooperatif); (h) Guru berperan sebagai fasilitator, motivator, dan pembimbing; (i) Masalah diformulasikan unuk memfokuskan dan merangsang pembelajaran; (j) Masalah adalah kendaraan untuk pengembangan keterampilan pemecahan masalah; dan (k) Informasi baru diperoleh melalui belajar mandiri.

\section{c. Manfaat Pembelajaran}

\section{Berbasis Masalah}

Menurut Hidayat (tt: 7), manfaat pembelajaran berbasis masalah, adalah: (a) Peserta didik lebih memahami konsep yang diajarkan sebab mereka sendiri yang menemukan konsep tersebut; (b) Melibatkan secara aktif memecahkan masalah dan menuntut keterampilan berpikir peserta didikyang lebih tinggi; (c) Pengetahuan tertanam berdasarkan skemata yang dimiliki peserta didiksehingga pembelajaran lebih bermakna; (d) Peserta didik dapat merasakan manfaat pembelajaran secara langsung, sebab masalah-masalah yang diselesaikan

langsung dikaitkan dengan kehidupan nyata, hal ini dapat meningkatkan motivasi dan ketertarikan peserta didik terhadap bahan yang dipelajari; Menjadikan peserta didik lebih mandiri dan dewasa, mampu memberi aspirasi dan menerima pendapat orang lain, menanamkan sikap sosial yang positif diantara peserta didik; dan (f) Pengkondisian peserta didik dalam belajar kelompok yang saling berinteraksi terhadap pembelajar dan temannya sehingga pencapaian ketuntasan belajar peserta didikdapat diharapkan.

\section{d. Langkah-langkah}

\section{Pembelajaran Berbasis}

\section{Masalah}

Pada dasarnya, PBM diawali dengan aktivitas peserta didik untuk menyelesaikan masalah nyata yang ditentukan atau disepakati. Proses penyelesaian masalah tersebut berimplikasi pada terbentuknya keterampilan peserta didik dalam 
PEDAGOGIKA

Jurnal Ilmu Pendidikan

Volume 9 (Nomor 2) 2018

menyelesaikan masalah dan berpikir

kritis serta sekaligus membentuk

pengetahuan baru.

Tabel 2Sintaksis Pembelajaran

Berbasis Masalah

\begin{tabular}{|c|c|}
\hline Tahap & $\begin{array}{l}\text { Aktivitas Guru dan } \\
\text { Peserta didik }\end{array}$ \\
\hline $\begin{array}{l}\text { Tahap } 1 \\
\text { Mengorienta } \\
\text { sikan } \\
\text { peserta didik } \\
\text { terhadap } \\
\text { masalah }\end{array}$ & 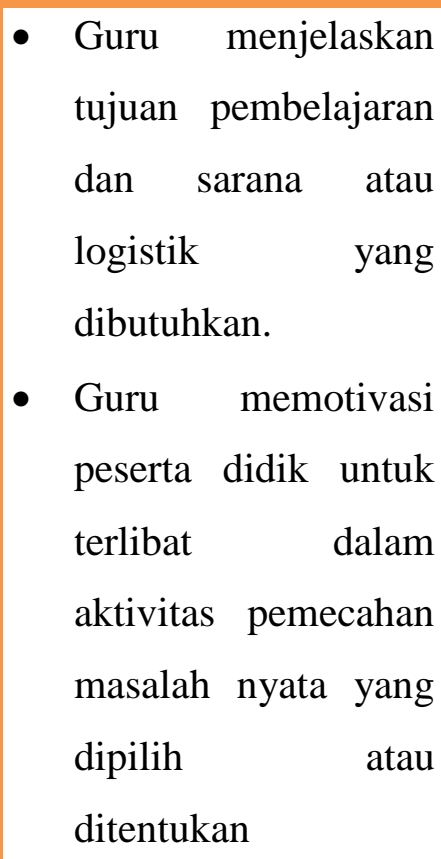 \\
\hline $\begin{array}{l}\text { Tahap } 2 \\
\text { Mengorgani } \\
\text { sasi peserta } \\
\text { didik untuk } \\
\text { belajar }\end{array}$ & $\begin{array}{l}\text { - Guru membantu } \\
\text { peserta didik } \\
\text { mendefinisikan dan } \\
\text { mengorganisasi tugas } \\
\text { belajar yang } \\
\text { berhubungan dengan } \\
\text { masalah yang } \\
\text { diorientasikan pada } \\
\text { tahap sebelumnya. }\end{array}$ \\
\hline
\end{tabular}

\begin{tabular}{|c|c|}
\hline Tahap & $\begin{array}{l}\text { Aktivitas Guru dan } \\
\text { Peserta didik }\end{array}$ \\
\hline $\begin{array}{l}\text { Tahap } 3 \\
\text { Membimbin } \\
\mathrm{g} \\
\text { penyelidikan } \\
\text { individual } \\
\text { maupun } \\
\text { kelompok }\end{array}$ & $\begin{array}{lr}\text { - Guru mendorong } \\
\text { peserta didik } & \text { untuk } \\
\text { mengumpulkan } & \\
\text { informasi } & \text { yang } \\
\text { sesuai } & \text { dan } \\
\text { melaksanakan } & \\
\text { eksperimen } & \text { untuk } \\
\text { mendapatkan } & \\
\text { kejelasan } & \text { yang } \\
\text { diperlukan } & \text { untuk } \\
\text { menyelesaikan } & \\
\text { masalah. } & \end{array}$ \\
\hline $\begin{array}{l}\text { Tahap } 4 \\
\text { Mengemban } \\
\text { gkan dan } \\
\text { menyajikan } \\
\text { hasil karya }\end{array}$ & $\begin{array}{l}\text { - Guru membantu } \\
\text { peserta didik untuk } \\
\text { berbagi tugas dan } \\
\text { merencanakan atau } \\
\text { menyiapkan karya } \\
\text { yang sesuai sebagai } \\
\text { hasil pemecahan } \\
\text { masalah dalam } \\
\text { bentuk laporan, } \\
\text { video, atau model. }\end{array}$ \\
\hline $\begin{array}{l}\text { Tahap } 5 \\
\text { Menganalisi } \\
\text { s dan } \\
\text { mengevalua } \\
\text { si proses } \\
\text { pemecahan }\end{array}$ & 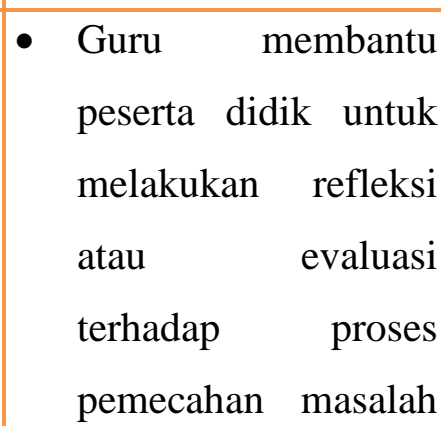 \\
\hline
\end{tabular}


PEDAGOGIKA

Jurnal Ilmu Pendidikan

Volume 9 (Nomor 2) 2018

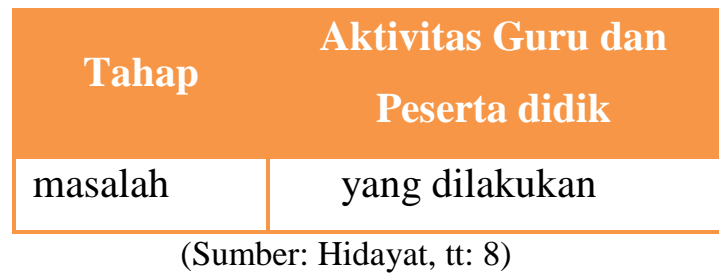

e. Keunggulan

dan

Kelemahan Pembelajaran

Berbasis Masalah

Trianto

(2014:68)

menyatakan beberapa keunggulan

pembelajaran berbasis masalah,

yaitu: (1) siswa lebih memahami

konsep yang diajarkan, sebab mereka

sendiri yang menemukan konsep

tersebut; (2) melibatkan siswa secara

aktif dalam memecahkan masalah

dan menumbuhkan keterampilan

berpikir siswa yang lebih tinggi; (3)

pengetahuan tertanam berdasarkan

skemata yang dimiliki siswa

sehingga pembelajaran lebih

bermakna; (4) siswa dapat

merasakan manfaat pembelajaran

sebab masalah yang diselesaikan

langsung dikaitkan dengan nyata, hal

ini dapat meningkatkan motivasi dan

ketertarikan siswa terhadap materi

bahan yang dipelajari;

menjadikan siswa lebih mandiri dan dewasa, mampu member aspirasi dan menerima pendapat orang lain, menanamkan sikap social dan positif di antara siswa; dan (6) pengondisian siswa dalam belajar kelompok yang saling berinteraksi terhadap pembelajar dan temannya, sehingga pencapaian ketuntasan belajar siswa dapat diharapkan.

Kelemahan dari pembelajaran berbasis masalah menurut Wina Sanjaya (2008) dalam Trianto (2014:69) yaitu: (1) manakala siswa tidak memiliki minat atau tidak mempunyai kepercayaan bahwa masalah yang dipelajari sulit untuk dipecahkan, maka mereka akan merasakan enggan untuk mencoba; (2) keberhasilan pembelajaran melalui problem-based learningini membutuhkan cukup waktu untuk persiapan; (3) tanpa pemahaman mengapa mereka berusaha untuk memecahkan masalah yang sedang dipelajari, maka mereka tidak akan belajar apa yang ingin mereka pelajari.

\section{Higher Order Thinking (HOT)}

Kurikulum 2013 merupakan penyempurnaan dari kurikulum sebelumnya yaitu Kurikulum Tingkat Satuan Pendidikan (KTSP). Kebijakan pemerintah ini diambil 
PEDAGOGIKA

Jurnal Ilmu Pendidikan

Volume 9 (Nomor 2) 2018

guna menghadapi tantangan abad 21

yaitu menciptakan masyarakat berpengetahuan (knowledge-based society. Oleh karena itu, kurikulum 2013 menuntut soal bentuk HOTuntuk membiasakan peserta didik kita dengan keterampilan berpikir kritis. Kurikulum 2013 juga menuntut materi pembelajarannya sampai metakognitif yang mensyaratkan peserta didik mampu untuk memprediksi, mendesain, dan memperkirakan.

Untuk dapat mengembangkan soal HOTmaka terlebih dahulu guru memerlukan pemahaman dalam hal pengertian HOT, HOT dalam Taksonomi Bloom dan Cara mengembangkan soal HOT.

\section{a. Pegertian Higher Order Thinking(Berpikir Tingkat Tinggi)}

\begin{tabular}{lr}
\multicolumn{1}{c}{ Higher } & Order \\
Thinking(HOT)didasari & oleh \\
taksonomi Bloom.Lee \& Choi dalam \\
artikel Computers \\
Education(2017) \\
menyatakan,"higher order thinking \\
became broadly recognized as away
\end{tabular}

of thinking that moves beyond memorization, recall, and comprehension to the analysis, evaluation, and creation of knowledge or artifacts." Menurut Lee \& Choi pemikiran tingkat tinggi secara luas dikenal sebagai cara berpikir yang prosesnya melebihi hafalan, recall, dan pemahaman terhadap informasi melalui analisis, evaluasi dan penciptaan pengetahuan atau artefak.

Stein \& Lane (1996) dalam Tony Thomson melalui Jurnal International Electronik Journal of Mathematics Education (2008) menyatakan bahwa higher order thinking adalah the use of complex, nonalgorithmic thinking to solve a task in which there is not a predictable, well-rehearsed approach or pathway explicitly suggested by the task, task instruction, or a worked out example. Stain \& Lane berpendapat bahwa berpikir tingkat tinggi adalah menggunakan pemikiran yang kompleks, berpikir non algoritmik untuk menyelesaikan tugas dimana ada yang tidak dapat diprediksi, 
menggunakan pendekatan yang berbeda dengan tugas yang sudah ada serta contoh yang diberikan.

Dari berbagai pendapat ahli di atas dapat disimpulkan bahwahigher order thinkingadalah cara berpikir yang kompleks, non algoritmik dan membutuhkan analisis untuk dapat menyelesaikan masalah yang tidak biasa.

\section{b. Soal Higher Order}

\section{Thinking $(\mathrm{HOT})$}

Melatih peserta didik untuk terampil berpikir tingkat tinggi dapat dilakukan guru dengan cara melatihkan soal-soal yang sifatnya mengajak peserta didik berpikir dalam level analisis, evaluasi dan mencipta/mengkreasi.Higher order thinkingdibagi menjadi empat kelompok yaitu pemecahan masalah, membuat keputusan, berfikir kritis dan berfikir kreatif (Saputra: 2015).

Berdasarkan hal di atas maka soal-soal penilaian hasil belajaruntuk menguji keterampilan berpikir peserta didik harus dirancang sedemikian rupa, sehingga dalam menjawab soal peserta didik melalui proses berpikir yang sesuai dengan kata kerja operasional taksonomi Bloom, baik pada soal pengetahuan, sikap maupun keterampilan. Dalam pembelajaran dinyatakan bahwa kemampuan peserta didik bukan hanya untuk menguasai sekumpulan pengetahuan yang berupa fakta-fakta, konsepkonsep, atau prinsip-prinsip saja tetapi juga merupakan suatu proses penemuan. Hal ini berarti peserta didik harus selalu diajak untuk belajar dengan menggunakan proses berpikir untuk menemukan konsepkonsep tersebut.

\section{c. Higher Order Thinking(HOT) dalam Taksonomi Bloom}

Taksonomi

Bloom merupakan wahana yang digunakan sebagai acuan untuk memahami cara berpikir peserta didik sejak tahun 1950-an hingga sekarang. Pada tahun 1990-an melalui suatu kelompok kerja yang dipimpin oleh Lorin Aderson, taksonomi Bloom tersebut diperbaikiguna menghadapi pembelajaran abad 21. Hasil dari pekerjaan tim tersebut adalah perbaikan struktur ranah kognitif 
PEDAGOGIKA

Jurnal Ilmu Pendidikan

Volume 9 (Nomor 2) 2018

yang dapat dilihat pada Tabel 2.3

berikut.

Tabel 3 Perbaikan Struktur Ranah

Kognitif

\begin{tabular}{|c|c|c|}
\hline $\begin{array}{c}\text { Tahapa } \\
\mathrm{n} \\
\text { Kogniti } \\
\mathrm{f}\end{array}$ & Taksonomi & $\begin{array}{c}\text { Taksonomi } \\
\text { Perbaikan } \\
\text { Anderson }\end{array}$ \\
\hline 1 & $\begin{array}{c}\text { Pengetahua } \\
\mathrm{n}\end{array}$ & Mengingat \\
\hline 2 & $\begin{array}{c}\text { Pemahama } \\
\mathrm{n}\end{array}$ & Memahami \\
\hline 3 & Penerapan & Menerapkan \\
\hline 4 & Analisis & $\begin{array}{c}\text { Menganalisi } \\
\mathrm{s}\end{array}$ \\
\hline 5 & Sintesis & Menilai \\
\hline 6 & Penilaian & $\begin{array}{c}\text { Menciptaka } \\
\mathrm{n}\end{array}$ \\
\hline
\end{tabular}

(Sumber:

Yulaelawati,

2007:79)

Berdasarkan Tabel 2.2

nampak jelas bahwa perbaikan penting yang dilakukan Anderson adalah dari kata benda menjadi kata kerja. Hal ini dilakukan karena taksonomi perlu mencerminkan berbagai bentuk berpikir dalam proses yang aktif, sehingga penggunaan kata kerja lebih sesuai daripada kata benda. Misalnya pada kata pengetahuan. Pengetahuan merupakan hasil dari berpikir bukan cara berpikir.Oleh karena itu kata pengetahuan mengalami perbaikan dan perubahan menjadi mengingat, karena kata mengingat menunjukkan proses berpikir tingkat awal. Demikian pula untuk kategori lainnya yaitu pemahaman diperbaiki menjadi memahami, penerapan menjadi menerapkan, dan analisis menjadi menganalisis.

Widodo (2006) menyatakan bahwa penjenjangan proses kognitif pada taksonomi bloom yang baru sama dengan taksonomi yang lama, hanya saja sifatnya lebih fleksibel. Dari pernyataan tersebut dapat dijelaskan bahwa perubahan taksonomi Bloom juga tejadi pada jenjang struktur kognitif seperti yang tampak pada tabel 3. Dimana menilai ditempatkan pada jenjang ke-5 setelah menganalisis. Selanjutnya mencipta ditempatkan pada jenjang ke-6 sebagai pengganti sintesis.

Perubahan

tersebut dilakukan guna menempatkan jenjang proses berpikir dari yang paling mudah ke proses penciptaan 
PEDAGOGIKA

Jurnal Ilmu Pendidikan

Volume 9 (Nomor 2) 2018

yang lebih rumit. Alasan perubahan tersebut cukup logis, dimana sesorang akan kesulitan menciptakan sesuatu sebelum ia mampu menilainya dengan berbagai pertimbangan dan pemikiran kritis. Sementara fleksibel itu sendiri berarti bahwa untuk dapat melakukan proses kognitif yang lebih tinggi tidak mutlak disyaratkan penguasaan proses kognitif yang lebih rendah. Selanjutnya Widodo (2015) menguraikan jenjang proses kognitif taksonomi Bloom revisi sebagai berikut: (1) Menghafal (Remember); (2) Memahami (Understand); (3) Mengaplikasikan (Applying; $\quad$ (4)Menganalisis (Analyzing);

Mengevaluasi/Menilai; dan (6) Membuat (create).

Dimensi proses kognitif HOTmenurut Anderson\& Krathwohl (2001) dapat dilihat pada tabel 4 berikut.

Tabel 4 Proses Kognitif HOT

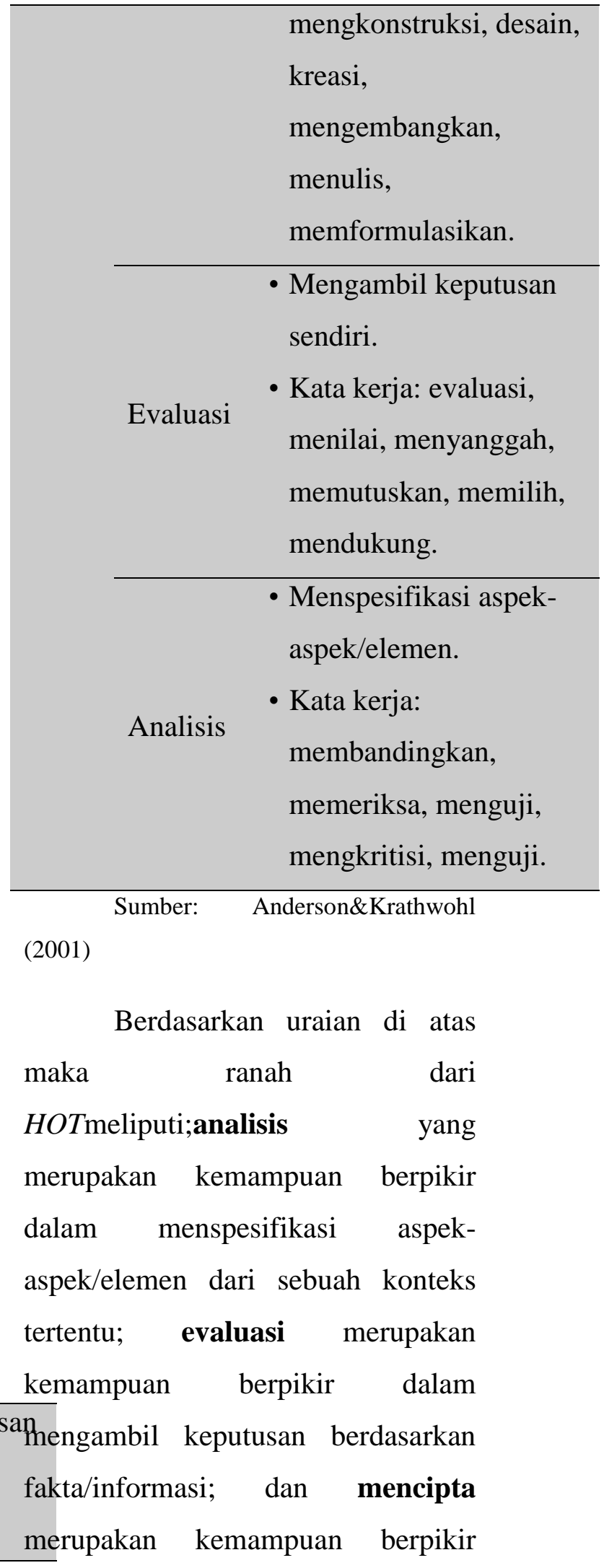

mengkonstruksi, desain,

kreasi,

mengembangkan,

menulis,

sendiri.

Kata kerja: evaluasi, menilai, menyanggah, memutuskan, memilih aspek/elemen

Kata kerja: membandingkan, memeriksa, menguji, mengkritisi, menguji.

(2001) maka ranah dari

- Mengkreasi ide/gagasaphengambil keputusan berdasarkan HOTS Mencipta sendiri.

- Kata kerja: 
PEDAGOGIKA

Jurnal Ilmu Pendidikan

Volume 9 (Nomor 2) 2018

dalam membangun gagasan/ideide.Berbagai keterampilan dalam di dalam HOTSmerupakan bagian dari taksonomi Bloom yaitu tiga level tertinggi yang meliputi analisis, evaluasi dan mencipta/mengkreasi. Untuk peserta didik tingkat dasar tidak semua keterampilan dapat dilatihkan melalui pemecahan soalsoal, tetapi kita dapat memilih yang sesuai dengan tingkat berpikir peserta didik tersebut dan mendesainnya menjadi soal yang mendorong peserta didik berpikir tingkat tinggi.

\section{d. Pengembangan SoalHigher Order Thinking(HOT)}

Pengembangan soal HOT memerlukan berbagai kriteria baik dari segi bentuk soalnya maupun konten materi subyeknya. Teknik penulisan soal-soal HOT baik yang berbentuk pilihan ganda atau uraian secara umum sama dengan penulisan soal tingkat rendah, tetapi ada beberapa ciri yang membedakannya.

Ada beberapa cara yang
dapat dijadikan pedoman oleh para
penulis soal untuk menulis butir soal yang menuntut berpikir tingkat tinggi, yakni materi yang akan ditanyakan diukur dengan perilaku sesuai dengan ranah kognitif Bloom pada level analisis, evaluasi dan mengkreasi, setiap pertanyaan diberikan dasar pertanyaan (stimulus) dan soal mengukur kemampuan berpikir kritis. Soal HOT selayaknya meminimalisir kemampuan mengingat kembali informasi (recall), tetapi lebih mengukur kemampuan: (1) Transfer satu konsep ke konsep lainnya, (2) Memproses dan menerapkan informasi, (3) Mencari kaitan dari berbagai informasi yang berbedabeda, (4) Menggunakan informasi untuk menyelesaikan masalah, dan (5) Menelaah ide dan informasi secara kritis.

Agar butir soal yang ditulis dapat menuntut berpikir tingkat tinggi, maka setiap butir soal selalu diberikan dasar pertanyaan (stimulus) yang berbentuk sumber/bahan bacaan seperti: teks bacaan, paragrap, teks drama, 
penggalan novel/cerita/dongeng, puisi, kasus, gambar, grafik, foto, rumus, tabel, daftar kata/simbol, contoh, peta, film, atau suara yang direkam. Tips menyusun soal HOT meliputi: (1) Gunakan Konteks Dunia Nyata, (2) Berikan Pertanyaan yang terkait analisis visual, (3) Tanyakan alasan dari jawaban yang diberikan, dan (4) Soal Pilihan ganda dapat mengukur HOT.

Adapun hal-hal penting yang perlu diperhatikan dalam penulisan soal HOT adalah sebagai berikut: (1) Pilih materi yang sesuai dengan indikator soal (disebut "stimulus"); (2) Periksa materi (stimulus). Apakah bermanfaat, merefleksikan kurikulum, menarik, relevan, dan cocok?Pertanyaan penting apa yang dapat diidentifikasi dari stimulus?;(3) HOTmeliputi menganalisis, mengevaluasi, dan mengkreasi; (4) Soal pilihan ganda dapat muncul dari pertanyaan HOT; (5) Untuk mendapatkan soal PG yang baik syaratnya harus ekstensif (menjangkau secara luas), ketat (teliti, cermat dan rapi), dan dipanelkan
Langkah-langkah Menyusun Soal HOTadalah: (1) Menganalisis KD yang dapat dibuatkan soal HOTS; (2) Menyusun kisi-kisi soal; (3) Menulis butir pertanyaan sesuai dengan kisi-kisi soal. Butir-butir pertanyaan ditulis agar sesuai dengan kaidah penulisan butir soal; (4) Membuat pedoman penskoran atau kunci jawaban.

Adapun bentuk soal yang dikembangkan dalam penelitian ini menggunakan bentuk tes uraian. Tes berbentuk uraian dapat digunakan untuk melatih keterampilan berpikir kritis dan mengukur HOT. Hal ini sesuai dengan pendapat Brookhart (2010: 33), Nitko \& Brookhart (2011: 143), Kubizyin \& Borich (2013: 143) dan Sumarna Surapranata (2007: 137) yang dikutip oleh Budiman \& Jailani (2014: 142). Pendekatan yang digunakan adalah seperangkat butir soal yang terdiri dari pengantar dan diikuti oleh pilihan jawaban atau latihan menafsirkan. Materi pengantar yang digunakan dalam membuat butir soal HOT adalah gambar, grafik, tabel, 
PEDAGOGIKA

Jurnal Ilmu Pendidikan

Volume 9 (Nomor 2) 2018

dan teks atau cerita yang melibatkan proses kognitif tingkat tinggi.

\section{C.METODE PENELITIAN}

Penelitian ini adalah penelitian dan pengembangan atau research and development $(R \& D)$ dengan model pengembangan Plomp tipe formative evaluation, yang merujuk pada prosedur Tessmer. Penelitian ini terdiri dari dua tahap yaitu preliminary dan tahap formative evaluation yang meliputi self evaluation, expert reviews dan one-to-one (low resistance to revision) dan small group serta field test(high resistance in revision) (Tessmer: 1993 dalam Zulkardi: 2002). Penelitian jenis ini ditujukan untuk menghasilkan soal HOTdengan ilustrasi tahapan formatif evaluation sebagai berikut:

\section{Low resistance to revision}
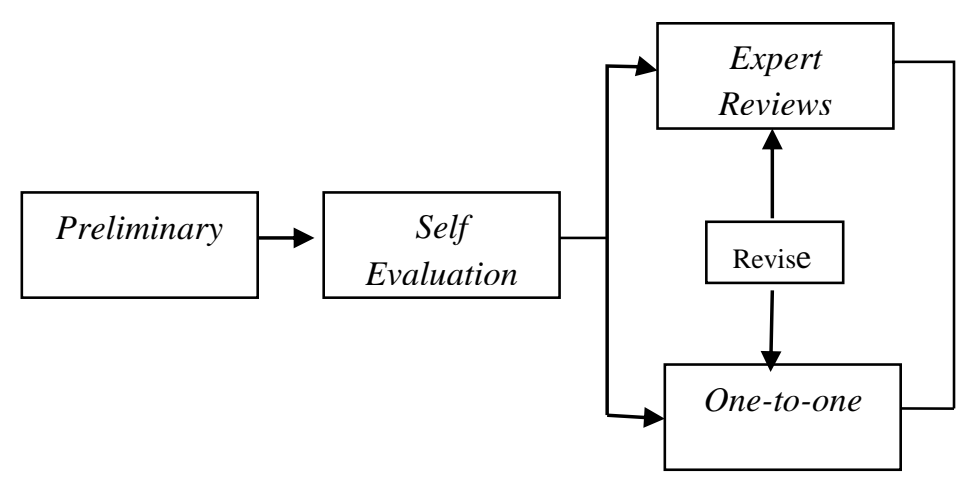

High resistance

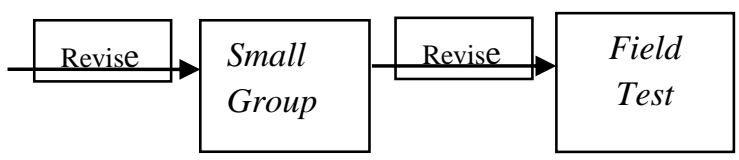

Gambar.1 Alur Desain Formative Evaluation Tessmer (dalam Zulkardi: 2006)

Penelitian ini dilaksanakan Oktober) selama semester gajil tahun selama dua bulan (September- pelajaran 2017/2018 di SDN No. 80 
PEDAGOGIKA

Jurnal Ilmu Pendidikan

Volume 9 (Nomor 2) 2018

Kota Tengah Kota Gorontalo jalan

Morotaitama Kelurahan Pulubala

Kecamatan Kota Tengah Kota

Gorontalo.

Subjek penelitian adalah adalah seluruh siswa kelas VI B yang berjumlah 25 orang, yang terdiri dari 12 orang laki-laki dan 13 orang perempuan.

\section{Pembahasan}

Hasil pengembangan dalam penelitian ini adalah instrumen soal berdimensi HOTberupa tes uraian pada pembelajaran tematik kelas VI SD semester 1 Tema 3Tokoh dan Penemuan yang valid dan reliabel. Soal-soal yang dikembangkan telah melalui 3 tahapan besar yaitu Desain, Self Evaluation, dan Prototyping (validasi, evaluasi dan revisi). Instrumen soal yang dikembangkan telah melalui dua tahap penilaian yaitu tahap pertama dilakukan untuk menilai tingkat validitas soal yang dilakukan oleh ahli pendidikan matematika (pengawas sekolah dan teman sejawat). Penilaian tahap kedua dilakukan melalui uji coba lapangan yang melibatkan 25 peserta didik. Fokus penilaian terletak pada karakteristik butir soal berdimensi HOT.

Proses pengembangan instrumen soal berdimensi HOT diuraikan secara rinci sebagai berikut:

1. Desain Soal

Dalam mendesain soal peneliti mengembangkan soal berdimensi HOT berdasarkan proses kognitif taksonomi Bloom revisi yaitu menganalisis (C4), mengevaluasi (C5), dan membuat/create (C6). Soal juga didesain dengan Bahasa Indonesia yang tepat dan sesuai dengan Ejaan Bahasa Indonesia (EBI), sehingga setiap pembaca memiliki pemahaman yang sama terhadap makna soal. Pengembangan soal berdimensi HOT juga mengacu pada indikator kemampuan berpikir kritis yaitu:

(1) Mampu merumuskan pokokpokok permasalahan; 
(2) Mampu mengungkap fakta yang dibutuhkan dalam menyelesaikan suatu masalah;

(3) Mampu memilih argument logis, relevan dan akurat;

(4) Mampu mendeteksi bias berdasarkan pada sudut pandang yang berbeda, dan;

(5) Mampu menentukan akibat dari suatu penyataan yang diambil sebagai suatu keputusan.

Desain soal pada penelitian ini juga didasarkan pada kurikulum 2013 serta Permendikbud No. 24 Tahun 2016 tentang Kompetensi Inti (KI) dan Kompetensi Dasar (KD) Matematika Matematika Kelas VI semester 1. Desain produk awal secara lengkap dapat dilihat dalam lampiran.

\section{Self Evaluation}

\section{- Analisis siswa}

Tahap ini meliputi analisis siswa dan analisis kurikulum. Analisis siswa bertujuan untuk menentukan 3 orang siswa yang menjadi tester (one to one)dan kelas ujicoba yang akan dilatih keterampilan berpikir kritisnya.

- Analisis kurikulum

Kegiatan yang dilakukan pada tahap ini adalah mengidentifikasi kompetensi dasar serta materi pembelajaran matematika kelas VI SD semester 1 kurikulum 2013. Cakupan materi soal berhubungan langsung dengan kegiatan pembelajaran menggunakan model pembelajaran berbasis masalah.

3. Prototyping (validasi, evaluasi, revisi)

Perangkat soal yang dihasilkan pada setiap prototipe divalidasi dengan melihat konten, konstruk, dan bahasa. Peneliti juga meminta pendapat dari viewer(teman sejawat) yang sudah berpengalaman dalam mengajar di SD. Pada tahap expert reviewspeneliti merevisi soal sesuai dengan saran 
PEDAGOGIKA

Jurnal Ilmu Pendidikan

Volume 9 (Nomor 2) 2018

validator dimana pembenahan lebih banyak dilakukan pada Ejaan Bahasa Indonesia (EBI), kalimat dalam soal, dan beberapa angka.

Soal yang telah divalidasi kemudian secara paralel diuji cobakan pada tiga orang peserta didik dengan kemampuan yang berbeda (rendah, sedang, dan tinggi). Pada penelitian ini yang menjadi subjek one to one adalah peserta didik kelas VIA SDN No. 80 Kota Tengah Kota Gorontalo. Untuk level kemampuan pandai soal berdimensi HOT diujikan kepada Monika A. Firmando, peserta didik berkemampuan sedang diujikan kepada Aulia Biki, dan peserta didik berkemampuan rendah diujikan kepada Moh. Eksa Buata. Interaksi yang dilakukan peneliti dengan peserta didik bertujuan untuk melihat kesulitan-kesulitan yang mungkin terjadi selama proses pengerjaan, sehingga diperoleh data tentang soal-soal yang perlu diperbaiki atau tidak.

Hasil dari interaksi yang dilakukan diperoleh masukan berupa komentar-komentar dari peserta didik, dimana sebagian besar sudah dapat membaca soal dan memahami maksud dari stimulus yang diberikan namun terdapat kesalahan dalam memaknai pertanyaan. Peserta didik dengan kemampuan tinggi dapat menyelesaikan soal sesuai waktu yang ditentukan namun untuk yang berkemampuan rendah memerlukan waktu lama dalam memahaminya. Kesalahan memaknai pertanyaan rata-rata terjadi pada butir soal nomor 1 . Kemampuan peserta didik dalam menghubungkan berbagai konsep untuk menentukan keputusan yang diambil terkait dengan pemecahan masalah juga masih kurang. Pada soal nomor 4 ratarata peserta didik mengalami kesulitan memahami prosedur penyelesaiannya.

Hal ini menunjukkan bahwa peserta didik pada tahap one to one secara umum sudah memiliki kemampuan penalaran yang baik walaupun pada beberapa butir tertentu belum bisa menyelesaikan soal-soal 
PEDAGOGIKA

Jurnal Ilmu Pendidikan

Volume 9 (Nomor 2) 2018

yang mempunyai level kognitif tinggi.

Berdasarkan one to one, self evaluation dan expert reviewsyang diberikan secara paralel maka desain awal direvisi dengan ketentuan sebagai berikut:

1. Beberapa kesalahan redaksi soal diperbaiki.

2. Soal yang kurang memancing keterampilan berpikir kritis diganti dengan soal yang memerlukan keterampilan berpikir kritis.

4. Uji coba small group

Soal-soal untuk melatih kemampuan berpikir kritis pada prototipe kedua diujicobakan pada small group yang terdiri dari 5 orang peserta didik kelas VIA SDN No. 80 Kota Tengah Kota Gorontalo. Mereka diminta mengerjakan soal-soal berdimensi HOT secara bertahap untuk mendapatkan gambaran waktu yang diperlukan peserta didik dalam menyelesaikan butirbutir soal sesuai dengan jumlah pertemuan. Hasil dari prototipe kedua kemudian direvisi untuk mendapatkan prototipe ketiga.

5. Field Test (Uji lapangan)

Soal yang dihasilkan pada prototipe ketiga selanjutnya diujicobakan pada subjek penelitian yaitu peserta didik kelas VIB SDN No. 80 Kota Tengah Kota Gorontalo. Soalsoal berdimensi HOT digunakan dalam proses pembelajaran berbasis masalah dengan jumlah pertemuan sebanyak dua kali. Setiap pertemuan berlangsung selama 105 menit. Pertemuan pertama jumlah soal yang diberikan 2 butir dan pertemuan kedua diberikan 3 butir soal. Setiap peserta didik menjawab pertanyaan pada buku tulis dan dikumpulkan sesuai waktu yang telah ditentukan selesai.

Data hasil pekerjaan peserta didik selanjutnya dianalisis untuk melihat potensial efek soal-soal berdimensi HOT untuk melatih keterampilan berpikir kritis melalui pembelajaran berbasis masalah. Dalam hal ini peneliti tidak mengukur tingkat 
PEDAGOGIKA

Jurnal Ilmu Pendidikan

Volume 9 (Nomor 2) 2018

keterampilan berpikir kritis

peserta didik.

\section{D.KESIMPULAN}

Prototipe soal-soal

berdimensi HOTyang dikembangkan dikategorikan valid. Valid tergambar dari hasil penilaian validator, dimana validator menyatakan baik berdasarkan konten, konstruk, dan bahasa. Berdasarkan proses pengembangan yang dilakukan diperoleh data bahwa prototipe soalsoal berdimensi HOT memiliki potensial efek terhadap hasil belajar . Hal ini terlihat dari hasil pekerjaan peserta didik pada saat proses pembelajaran dengan kategori baik.

$$
\text { Penggunaan soal-soal }
$$

berdimensi HOTmemerlukan waktu yang cukup lama, sehingga guru perlu terus mengembangkan soalsoal tersebut dalam jumlah yang banyak agar siswa lebih terlatih keterampilannya.

\section{REFERENSI}

Arends, R.I. 1997. Classroom Instruction and Management.
New York: The McGraw-Hill

Companies, Inc.

Ayuningtyas, N., \&Rahaju, E. B. 2013. Proses Penyelesaian Soal Higher Order Thinking Materi Aljabar Siswa Smp Ditinjau Berdasarkan Kemampuan Matematika Siswa.(online) Vol. 2 No. 2.http://ejournal.unesa.ac.id/ article/4718/30/article.pdf diakses 15 Januari 2017)

Aka, Kukuh Andri. 2012.

Pembelajaran Tematik

Terpadu. (Online)

http://belajarpendidikanku.bl ogspot.co.id/2012/07/pembel ajaran-tematikterpadu.html diakses tanggal 20 Januari 2017 pukul 11.11

Budiman, A. \& Jailani. 2014. Pengembangan Instrumen Asesmen Highher Order Thinking Skills (HOTS) pada Mata Pelajaran Matematika SMP Kelas VIII Semester 1. Tesis (online) http://eprints.uny.ac.id/12942 /diakses tanggal 29 Desember 2017 pukul 09.15

Dahlan, Ahmad. 2015. Pembelajaran Tematik Integratif Pada Sekolah Dasar. (online) http://www.eurekapendidikan .com/2015/04/pembelajarantematik-integratif-pada.html diakses tanggal 20 Januari 2017 pukul 9.30 
PEDAGOGIKA

Jurnal Ilmu Pendidikan

Volume 9 (Nomor 2) 2018

Depdiknas. 2007. Peraturan Menteri

Pendidikan Nasional

Republik Indonesia Nomor

20, Tahun 2007, tentang

Standar Penilaian

Pendidikan.

Faiq, Muhammad. 2014 Konsep

Pembelajaran Tematik

Terpadu Menurut Kurikulum

2013(Online)

http://penelitiantindakankelas

.blogspot.co.id/2014/05/kons

ep-pembelajaran-tematik-

terpadu.html di akses tanggal

20 Januari 2017 pukul 19.15

Hartini\& Sukardjo. 2015.

Pengembangan Higher Order

Thinking Multiple Choise

Test Untuk Mengukur

Keterampilan Berpikir Kritis

IPA Kelas VI SMP/MTs.

Jurnal Inovasi Pendidikan

IPA (Online), Vol. 1 No. 1.

(http://jurnal.uny.ac.id,

Diakses 8 April 2017)

Okti, Wulie. (2014). TIMSS (Trends

International Mathematics

and Science Study) (online)

http://wulieokti.blogspot.co.i

d/2014/04/timss-trends-

international-

mathematics.htmldiakses 15

Januari 2017 pukul 23.04

Permendikbud No 23 Thn 2016

tentang Standar Penilaian

Pendidikan (online)

http://bsnp-indonesia.org/wp-

content/uploads/2009/09/

Permendikbud_Tahun2016_

Nomor023.pdf diakses 13

Januari 2017 pukul 11.30
Permendiknas No 22 Th 200602.

BAB II Kerangka Dasar dan

Struktur Kurikulum

Rahmawati. 2016. Hasil TIMSS

2015. (online)

http://puspendik.kemdikbud.g

o.id/seminar/upload/Rahmaw

ati-

Seminar\%20Hasil\%20TIMS

S\%202015.pdfdiakses 28

Desember 2016

Saleh, Marhamah. 2013. Problem

Based Learning. (online) jurnal ilmiah Didaktika Vol.

XIV, No 1 Agustus 2013

http://jurnal.ar-

raniry.ac.id/index.php/didakti

ka/article/viewFile/497/415 di

akses tgl 18 Juni 2016 pukul

17.53

Sart, G., 2014. The effects of the development of metacognition on project-based learning. Procedia Soc. Behav. Sci. 152, 131-136.

Sudrajat, A. 2012. Permendiknas

Nomor 16 Tahun 2007

tentang Standar Kualifikasi

akademik dan Kompetensi

Guru.(online).

(https://akhmadsudrajat.files.

wordpress.com/

2012/01/nomor-16-tahun-

2007-dan-lampiran.pdf,

diakses 11 Januari 2017)

Tularam, Gureduo Anand. 1994.

Higher Order Thinking and 
PEDAGOGIKA

Jurnal Ilmu Pendidikan

Volume 9 (Nomor 2) 2018

Mathematics. (online)

http://www.merga.net.au/doc uments/RP_Tularam_1994.pd

f. Diakses 14 januari 2017 pukul 18.30

Undang-UndangRI Nomor 20 Tahun 2003 tentang Sistem Pendidikan

Nasional(online)http://pendis. kemenag.go.id/pai/file/doku men/SisdiknasUUNo.20

Tahun2003.pdfdiakses tanggal 15 Januari 2017 14.10

Van de Walle, J. A. 2007.

Elementary and middle schoolmathematics: teaching developmentally, ( $6^{\text {th }}$ ed). United State of America: Pearson Education, Inc.
Vaghar Seyyedin, A., Vanaki, Z., Taghi, S., Molazem, Z., 2009. The effect of guided reciprocal peer questioning (GRPQ) on nursing students' critical thinking and metacognition skills. Iran. J. Med. Educ. 8 (2), 333-339

Widiantari, Ni Kt. M. P., Suarjana, I Md. \& Kusmariyatni N. 2016. Analisis Kemampuan Berpikir Kritis Siswa Kelas IV Dalam Pembelajaran Matematika. E-Jounal PGSD Universitas Pendidikan Ganesha(online), Vol.4 No.1 (http://ejounal.pgsdundiksha.id, diakses 22 mei 2017) 